\title{
KAJIAN KUALITAS MIE KERING TERSUBSTITUSI TEPUNG LIMBAH TEMPE
}

\author{
Study on the Quality of Dry Noodles from the Substitution of Tempeh Waste Flour \\ Robitotuzzakiyah* dan Rekna Wahyuni \\ Program Studi Ilmu dan Teknologi Pangan, Fakultas Pertanian, Universitas Yudharta Pasuruan \\ *Penulis korespondensi, email: alobiet1996@ gmail.com ${ }^{1)}$
}

\begin{abstract}
Dried noodle is noodles that have been experiencing draining until the water levels reached $8-10 \%$, hold in store for a long time because the moisture content is reduced so that it is difficult to grow mushrooms and molds. The main raw materials used for a manufacture of these noodles was plain flour. The purpose of this research is to substituting it with wheat flour flour waste fermented soybean in blocks (soy epidermis) in making noodles and knowing the proportion of waste fermented soybean in blocks flour (soy epidermis) on dried noodle quality best seen from the physical, chemical and organoleptic. This research method using RAK (Random Design Group) and one factor is 5 times the treatment. Comparison of waste fermented soybean in blocks flour : flour (10:90, 20:80, 30:70, 40:60, 50:50) grams. The observations made with the analysis of ANOVA and with BNT in hose beliefs 5\% and 1\%. While the analysis of organoleptic using of Friedman test and to find out the best treatment using index effectiveness test of de Garmo modification Susrini. The results showed the best treatment refractory sempel Al i.e. the proportion of flour and flour a 90 grams waste fermented soybean in blocks flour 10 grams chemical value protein $10.70 \%$ and water $9.65 \%$, tensile strength 1.49 (N) cooking time (minutes) 2.42, as well organoleptic taste 3 (neutral), color 3.85 (love), flavor 4 (like), and texture 4 (like).
\end{abstract}

Keywords: dried noodles, flour, waste fermented soybean in blocks, substitution

\begin{abstract}
ABSTRAK
Mie kering merupakan mie yang telah mengalami pengeringan sampai kadar air mencapai 8$10 \%$, tahan untuk di simpan dalam waktu yang lama karena kandungan air yang berkurang sehingga sulit di tumbuhi jamur dan kapang. Bahan baku utama yang digunakan untuk pembuatan mie ini adalah tepung terigu. Tujuan dari penelitian ini adalah untuk mensubtitusikan tepung terigu dengan tepung limbah tempe (kulit ari kedelai) dalam pembuatan mie dan mengetahui proporsi tepung limbah tempe (kulit ari kedelai) pada pembuatan mie kering terbaik dilihat dari mutu fisik, kimia dan organoleptiknya. Penelitian ini menggunakan metode RAK (Rancangan Acak Kelompok) dengan satu faktor 5 kali perlakuan. Perbandingan tepung limbah tempe : tepung terigu $(10: 90,20: 80,30: 70,40: 60,50: 50)$ gram. Hasil pengamatan dilakukan menggunakan analisa secara ANOVA dan BNT dengan selang kepercayaan 5\% dan 1\%. Sedangkan analisa organoleptik menggunakan Uji Friedman dan untuk mengetahui perlakuan terbaaik menggunakan uji Indeks Efektifitas de Garmo modifikasi Susrini. Hasil penelitian menunjukkan perlakuan terbaik terdapat pada sempel A1 yaitu proporsi tepung terigu $90 \mathrm{gr}$ dan tepung limbah tempe $10 \mathrm{gr}$ dengan nilai kimiawi kadar protein 10,70\% dan kadar air 9,65\%, nilai fisik daya patah 1,49 (N) cooking time 2,42 (menit), serta organoleptik rasa 3 (netral), warna 3,85 (suka), aroma 4 (suka), dan tekstur 4 (suka).
\end{abstract}

Kata Kunci : mie kering, tepung, limbah tempe, subtitusi 


\section{PENDAHULUAN}

Upaya diversifikasi produk olahan akhir-akhir ini semakin berkembang pesat seiring dengan bertambahnya kecrdasan masyarakat, terutama produk dari limbah yang masih banyak zat gizinya seperti limbah padat tempe. Limbah padat tempe merupakan limbah dari produksi tempe, biasanya kulit ari biji kedelai hanya dimanfaatkan sebagai pakan ternak. Pipit (2009) menyebutkan bahwa kulit ari ini memiliki banyak kandungan yaitu bahan kering 14,26\%, protein kasar 13,27\%, lemak kasar 1,27\%, serat kasar 51,59\%, abu 2,34\% dan TDN 64,55\%.

Mie kering merupakan mie yang telah mengalami pengeringan sampai kadar air mencapai $8-10 \%$, tahan untuk di simpan dalam waktu yang lama karena kandungan air yang berkurang sehingga sulit dibtumbuhi jamur dan kapang (Astawan, 2008). Mie ini juga duganari oleh masyarakat mulai dari anak-anak sapai orang tua. Bahan baku yang dugunakan untuk mie ini adalah tepung terigu, tapi dalam hal ini akan di subtitusi dengan tepung ampas tempe yang mengandung cukup tinggi serat. Dengan adanya pemanfaatan limbah dari kulit ari kedelai dapat mendukung program pemerintah tentang diversifikasi pangan yaitu penggunaan bahan pangan lokal yang harganya relatif lebih murah dan banyak tersedia di Indonesia yang tercantum dalam PP 68/2002 pasal 9 dengan tujuan mengurangi ketergantungan terhadap bahan pangan impor seperti tepung terigu.

Substitusi tepung limbah tempe berpengaruh terhadap rasa, aroma, warna, tekstur dan kandungan guzu mie kering sehingga perlu dikaji prosentase substitusi limbah tempe yang paling tepat sehingga memiliki kualitas fisiko kimia dan organoleptik yang baik agar dapat menghasilkan produk yang sehat, mempunyai mutu tinggi dan disukai oleh konsumen.

\section{METODE PENELITIAN}

\section{Alat dan bahan}

Alat alat yang digunakan dalam pembuatan mie kering adalah oven tiga berlian, loyang, kompor gas rinnai, blender philips, baskom, timbangan digital camry, pasta machine atlas marcato. Alat yang digunakan dalam analisa adalah labu ukur (Pyrex), labu kjedal (Buchi), beaker glass (Pyrex), gelas ukur (Pyrex), labu Enlenmeyer (Pyrex), timbangan digital analitik (Denver Instrumen M-310), oven (Memmert), kertas saring (Whatman), staif, pendingin balik, bola hisap.

Bahan yang digunakan dalam pembuatan mie kering adalah tepung terigu cakra kembar Bogasari, tepung tapioka Rose Brand, tepung limbah tempe yang didapatka di home industri rumah tempe dusun Kutukan desa Lecari Kecamatan Sukorejo Kabupaten Pasuruan Jawa Timur, telur ayam ras, garam dapur cap kapal, air dan baking powder cap Cendrawasih. Bahan yang digunakan untuk analisa antara lain, alkohol 95\%, HCL $0.10 \mathrm{~N}, \mathrm{NaOH} 40 \%$, $\mathrm{H}_{2} \mathrm{SO}_{4}$, table Kjehdal, indicator PP, Arsenomolybdat, $\mathrm{K}_{2} \mathrm{SO}_{4} 10 \%$, Pethrolium Eter, Nelson A, Nelson B.

Rancangan percobaan yang digunakan adalah Rancangan acak kelompok (RAK) yang terdiri dari 1 faktor yaitu proporsi tepung limbah tempe dan tepung terigu dengan 5 kali perlakuan dan 3 kali ulangan.

1. $\mathrm{A} 1=$ Tepung limbah tempe $10 \mathrm{~b} / \mathrm{b}$ dan Tepung Terigu $90 \mathrm{~b} / \mathrm{b}$ (total 100 gram)

2. $\mathrm{A} 2=$ Tepung limbah tempe $20 \mathrm{~b} / \mathrm{b}$ dan Tepung Terigu $80 \mathrm{~b} / \mathrm{b}$ (total 100 gram)

3. $\mathrm{A} 3=$ Tepung limbah tempe $30 \mathrm{~b} / \mathrm{b}$ dan Tepung Terigu $70 \mathrm{~b} / \mathrm{b}$ (total 100 gram)

4. $\mathrm{A} 4=$ Tepung limbah tempe $40 \mathrm{~b} / \mathrm{b}$ dan Tepung Terigu $60 \mathrm{~b} / \mathrm{b}$ (total 100 gram)

5. $\mathrm{A} 5=$ Tepung limbah tempe $50 \mathrm{~b} / \mathrm{b}$ dan Tepung Terigu $50 \mathrm{~b} / \mathrm{b}$ (total 100 gram)

\section{Pelaksanaan Penelitian}

Proses pembutan mie kering limbah tempe melalui 2 tahap yaitu tahap 1 pembuatan tepung limbah tempe yang 
berasal dari kulit ari kedelai sisa pembuatan tempe dan tahap 2 yaitu pembuatan mie kering limbah tempe.

Pembuatan tepung limbah tempe dimulai dari kulit ari biji kedelai yang sudah dicuci bersih kemudian dilakukan pengukusan, pada saat pengukusan digunakan daun jeruk perut yang dicampur pada air kukusan untuk mengurangi aroma langu pada kulit ari biji kedelai, $1 \mathrm{~kg}$ kulit ari biji kedelai ditambahkan 3 gram daun jeruk purut, pengukusan dilakukan selama 15 menit, kemudian dilanjutkan dengan proses pengeringan bisa dilakukan dengan mesin pengering atau dengan panas sinar matahari langsung sampai kulit ari biji kedelai benar- benar kering sehingga mudah digiling, proses terakhir pembuatan tepung kulit ari biji kedelai yaitu digiling dengan mesin penggiling untuk tepung dan tepung kulit ari biji kedelai sudah bisa digunakan sebagai substitusi maupun bahan dasar.

Pembuatan mie kering limbah tempe memerlukan 7 proses yang pertama persiapan bahan, yang kedua pencampuran bahan yang dilakukan selama \pm 10 menit hingga bahan menjadi homogen dan mendapatkan hidrasi, yang ketiga pelempengan atau pemipihan adonan untuk membentuk lembaran, yang keempat pencetakan dilakukan menggunakan noodles maker menjadi untaian mie, yang kelima pengukusan dilakukan selama \pm 3 menit, yang keenam pendinginan dilakukan \pm 10 - 15 menit, yang ketujuh pengeringan dilakukan dengan menggunakan pengering kabinet atau oven dengan suhu $\pm 60{ }^{\circ} \mathrm{C}$ selama 8 - 10 jam.

Pengamatan yang dilakukan meliputi uji laboratorium dan organoleptik dengan meliputi analisa fisik, kimia dan organoleptik. Analisa fisik kimia meliputi kadar air, kadar protein, dan daya patah. Sedangkan sifat organoleptik meliputi warna, rasa, tekstur dan aroma terhadap kesukaan (hedonic) skor menggunaan 20 orang panelis dari kategori tidak terlatih.
Analisa data fisiko kimia dilakukan secara ANOVA dengan selang kepercayaan $5 \%$ dan $1 \%$. Apabila ditemukan pengaruh nyata terhadap salah satu variebel maka dilanjutkan dengan uji beda nyata terkecil (BNT). Untuk uji organoleptik menggunakan uji Friedman. Uji perlakuan terbaik fisiko kimia dan organoleptik menggunakan uji Indeks Efektifitas De Garmo. et al., (1984) yang dimodifikasi oleh Susrini (2003).

\section{HASIL DAN PEMBAHASAN}

\section{Kadar Protein}

Berdasarkan hasil analisis kadar protein mie kering limbah tempe diperoleh rata-rata kadar protein $8,13 \%$ sampai $10,70 \%$. Analisis ragam menunjukkan bahwa substitusi tepung limbah tempe berpengaruh nyata terhadap kadar protein mie kering yang dihasilkan, perlakuan substitusi terbaik terdapat pada perlakuan A1 (tepung terigu 90gr : tepung limbah tempe 10gr) dan perlakuan terendah pada A5 (tepung terigu 50gr : tepung limah tempe 50 gr). Rerata kadar protein mie kering limbah tempe juga dapat dilihat pada gambar 1.

Dari gambar diatas menunjukkan bahwa semakin tinggi proporsi tepung limbah tempe dan semakin rendah proporsi tepung terigu maka kadar protein mie kering yang dihasilkan semakin rendah, hal ini dikarenakan kadar protein pada tepung limbah tempe lebih rendah daripada kadar protein pada tepung terigu. Pipit (2009) limbah tempe memiliki kandungan protein kasar 13,27\%. Sedangkan menurut Bogasari (2011) kadan protein dalam tepung terigu 12 - $14 \%$. Meningkatnya proporsi tepung terigu akan semakin meningkatkan kadar protein pada mie kering begitu pula sebaliknya, meningkatnya proporsi tepung limbah tempe maka semakin rendah kadar protein pada mie kering. 




Keterangan : A1 (Tepung limbah tempe 10gr dan Tepung Terigu 90 gr). A2 (Tepung limbah tempe $20 \mathrm{gr}$ dan Tepung Terigu 80gr). A3 (Tepung limbah tempe $30 \mathrm{gr}$ dan Tepung Terigu 70gr). A4 (Tepung limbah tempe 40gr dan Tepung Terigu 60gr). A5 (Tepung limbah tempe 50gr dan Tepung Terigu 50gr).

Gambar 1. Kadar protein mie kering tersubstitusi tepung limbah tempe

\section{Kadar Air}

Berdasarkan hasil analisis kadar air mie kering limbah tempe diperoleh rata-rata kadar air 7, 44\% sampai 8, 86\%. Analisis ragam menunjukkan bahwa substitusi tepung limbah tempe berpengaruh nyata terhadap kadar air mie kering yang dihasilkan, perlakuan substitusi terbaik terdapat pada perlakuan A5 (tepung terigu 50gr : tepung limbah tempe 50gr) karena paling mendekati dengan syarat mutu mie kering yang sudah ditetapkan oleh BSN yaitu sebesar $8 \%$. Rerata kadar air mie kering limbah tempe juga dapat dilihat pada Gambar 2.

Dari Gambar 2 menunjukkan bahwa semakin tinggi proporsi tepung limbah tempe dan semakin rendah proporsi tepung terigu maka kadar air mie kering yang dihasilkan semakin rendah, hal ini dikarenakan kandungan protein yang semakin sedikit di dalam mie kering. Didalam tepung terigu mengandung protein yang memiliki gugus hidrofilik yang dapat meningkatkan penyerapan air (Winarti,dkk, 2017).

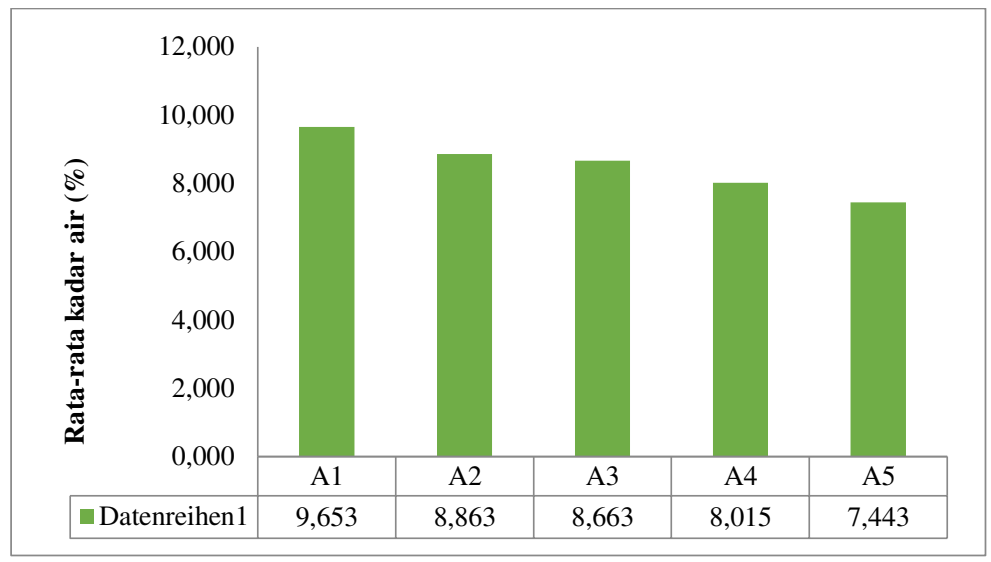

Keterangan : A1 (Tepung limbah tempe 10gr dan Tepung Terigu 90 gr). A2 (Tepung limbah tempe $20 \mathrm{gr}$ dan Tepung Terigu 80gr). A3 (Tepung limbah tempe $30 \mathrm{gr}$ dan Tepung Terigu $70 \mathrm{gr}$ ). A4 (Tepung limbah tempe 40gr dan Tepung Terigu 60gr). A5 (Tepung limbah tempe 50gr dan Tepung Terigu 50gr).

Gambar 2. Kadar air mie kering tersubstitusi tepung limbah tempe 


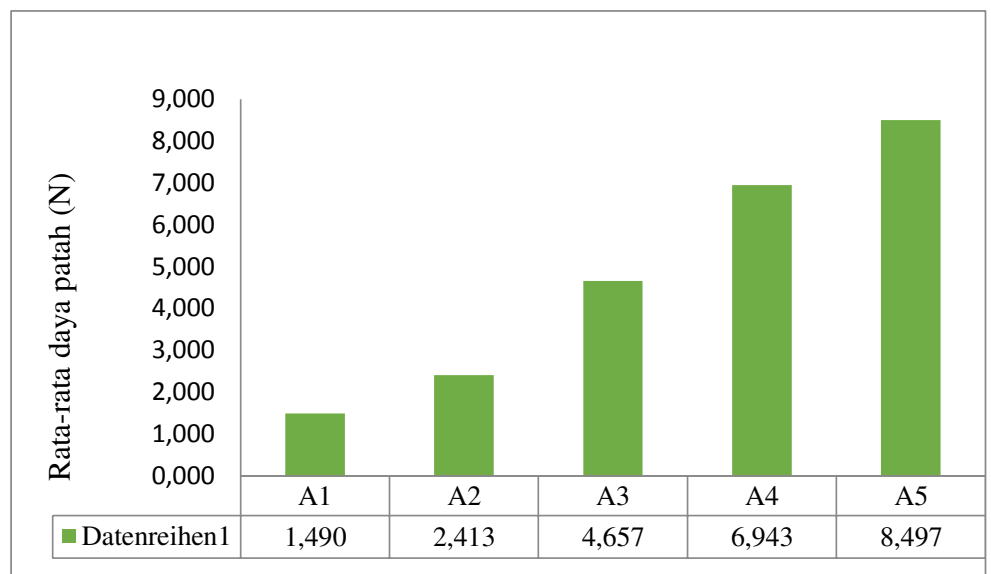

Keterangan : A1 (Tepung limbah tempe $10 \mathrm{gr}$ dan Tepung Terigu 90 gr). A2 (Tepung limbah tempe $20 \mathrm{gr}$ dan Tepung Terigu 80gr). A3 (Tepung limbah tempe 30gr dan Tepung Terigu 70gr). A4 (Tepung limbah tempe 40gr dan Tepung Terigu 60gr). A5 (Tepung limbah tempe 50gr dan Tepung Terigu 50gr).

Gambar 3. Daya patah mie kering tersubstitusi tepung limbah tempe

\section{Daya Patah}

Berdasarkan hasil analisis daya patah mie kering limbah tempe diperoleh rata-rata kadar air 1,49 $(\mathrm{N})$ sampai 8,50 $(\mathrm{N})$. Analisis ragam menunjukkan bahwa substitusi tepung limbah tempe berpengaruh nyata terhadap kadar air mie kering yang dihasilkan, perlakuan substitusi terbaik terdapat pada perlakuan A1 (tepung terigu 90gr : tepung limbah tempe 10gr) karena semakin kecil daya patah maka kekerasan semakin besar mengakibatkan mie tidak mudah patah dan remuk/ hancur. Rerata daya patah mie kering limbah tempe juga dapat dilihat pada Gambar 3.
Dari gambar menunjukkan bahwa semakin tinggi proporsi tepung limbah tempe maka akan semakin tinggi daya patah yang dihasilkan. Semakin tinggu tepung limbah tempe maka semakin tinggi serat yang ada di dalam mie kering. Kandungan serat limbah tempe adalah $59,8 \%$ (Yurleni : 2017) yang mengakibatkan kandungan serat dalam mie ikut naik dan mengakibatkan daya patah mie ikut naik. Semakin tinggi serat maka tekstur produk yang dihasilkan lebih kokoh dan kuat akibatnya produk menjadi lebih keras dan daya patah meningkat (Winarno, 2004).

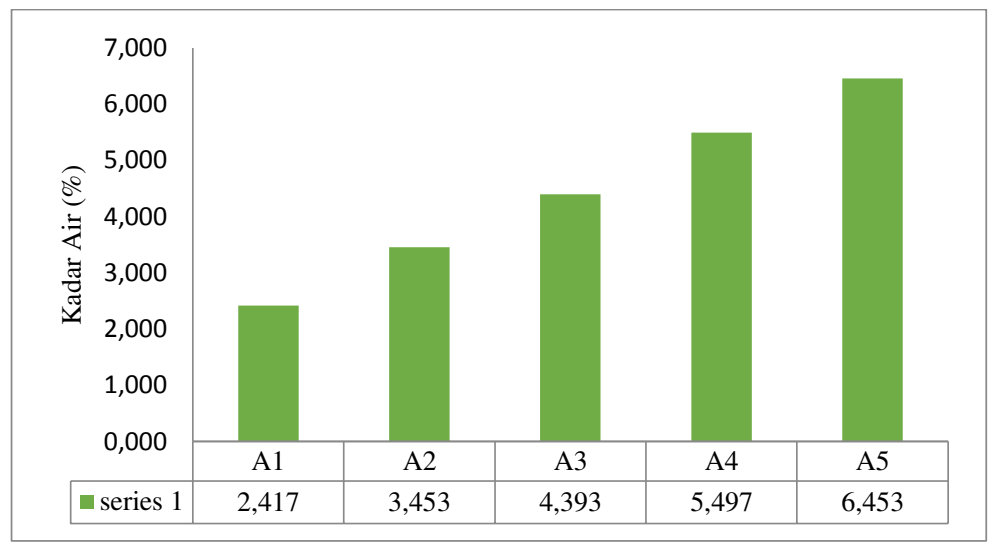

Keterangan : A1 (Tepung limbah tempe 10gr dan Tepung Terigu 90 gr). A2 (Tepung limbah tempe 20gr dan Tepung Terigu 80gr). A3 (Tepung limbah tempe 30gr dan Tepung Terigu 70gr). A4 (Tepung limbah tempe 40gr dan Tepung Terigu 60gr). A5 (Tepung limbah tempe 50gr dan Tepung Terigu 50gr). 
Gambar 4. Cooking Time mie kering tersubstitusi tepung limbah tempe

\section{Cooking Time}

Berdasarkan hasil analisis kadar air mie kering limbah tempe rata-rata cooking time 2,42 (menit) sampai 6,45 (menit). Analisis ragam menunjukkan bahwa substitusi tepung limbah tempe berpengaruh tidak nyata terhadap cooking time mie kering yang dihasilkan, perlakuan substitusi terbaik terdapat pada perlakuan A1 (tepung terigu 90gr : tepung limbah tempe 10gr), semakin pendek waktu pemasakan maka semakin bagus kualitas mie. Rerata cooking time mie kering limbah tempe juga dapat dilihat pada gambar histogram 4.

Dari data menunjukkan bahwa semakin tinggi proporsi tepung limbah tempe maka akan semakin lama cooking timenya. Semakin banyak tepung limbah tempe yang digunakan maka semakin sedikit tepung terigu yang digunakan mengakibatkan kandungan protein yang ada dalam mie kering. Tepung terigu mampu mengandung protein tinggi yang mampu mnyerap air yang tinggi (Halwan dkk : 2015). Khomsan dkk (2008) menyebutkan tingginya penyerapan air akan mempuat proses pemasakan semakin singkat. Sedangkan dalam tepung limbah tempe memiliki kandungan serat yang tinggi mengakibatkan air sulit untuk masuk kedalam granula-granula mie dan mengakibatkan proses glatinisasi menjadi tidak maksimal (Winarno, 2004).

\section{Uji Organoleptik}

Uji organoleptik dilakukan pada 5 sempel produk mie limbah tempe dengan menggunakan 20 orang panelis dengan spesifikasi tidak terlatih yang meliputi uji rasa, aroma, warna dan tekstur. Uji organoleptik dilakukan agar bisa mengetahui daya terima konsumen terhadap produk yang peneliti buat (Askar dkk, 2005). 5 sempel produk yang di ujikan yakni terdiri atas subtitusi tepung limbah tempe sebanyak 10\%, 20\%, 30\%, 40\%, 50\% dari $100 \mathrm{gr}$ tepung terigu yang mengakibatkan rasa, aroma, warna dan tektur yang dihasilkan berbeda.

\section{Rasa}

Dari uji organoleptik terhadap rasa mie kering yang dihasilkan dapat dilihat pada Gambar 5. Dari gambar di atas dapat diketahui bahwa rata-rata hasil uji organoleptik rasa yang dilakaukan 20 panelis lebih menyukai prodak yang lebih sedikit tersubtitusi tepung limbah tempe yaitu A1 dan A2 dengan subtitusi 10\% dan $20 \%$ dengan rata-rata nilai 3 (netral) dan penilaian terendah terdapat pada A5 dengan subtitusi $50 \%$ dan $50 \%$ dengan rata-rata nilai 2 (tidak suka).




Gambar 5. Organoleptik rasa mie kering tersubstitusi tepung limbah tempe

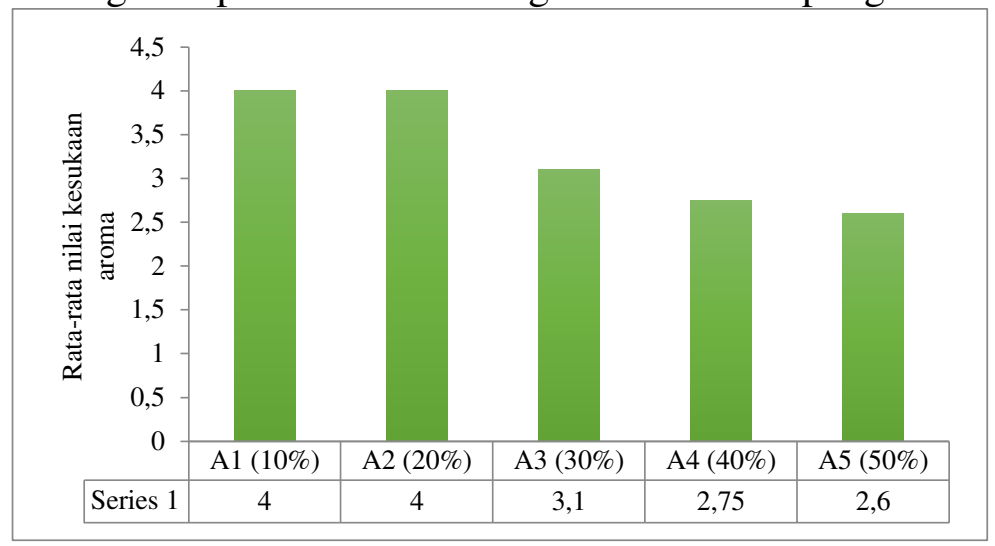

Keterangan : A1 (Tepung limbah tempe 10gr dan Tepung Terigu 90 gr). A2 (Tepung limbah tempe $20 \mathrm{gr}$ dan Tepung Terigu 80gr). A3 (Tepung limbah tempe 30gr dan Tepung Terigu 70gr). A4 (Tepung limbah tempe 40gr dan Tepung Terigu 60gr). A5 (Tepung limbah tempe 50gr dan Tepung Terigu 50gr).

Gambar 6. Organoleptik aroma mie kering tersubstitusi tepung limbah tempe

\section{Aroma}

Dari uji organoleptik terhadap aroma mie kering yang dihasilkan dapat dilihat pada Gambar 6.

Dari gambar diatas dapat diketahui bahwa rata-rata nilai yang dapat mempelihatkan kesukaan 20 orang panelis yaitu pada perlakuan 1 dan 2 yaitu A1 dan A2 dengan subtitusi $10 \%$ dan $20 \%$ dengan ratarata nilai adalah 4 (suka) dan penilaian terendah terdapat pada A5 dengan subtitusi $50 \%$ dan $50 \%$ dengan rata-rata nilai 2.6 (netral).

\section{Warna}

Dari uji organoleptik terhadap aroma mie kering yang dihasilkan dapat dilihat pada gambar 7. Dari gambar diatas dapat diketahui bahwa rata-rata nilai yang dapat mempelihatkan kesukaan 20 orang panelis yaitu pada perlakuan 1 yaitu A1 dengan subtitusi $10 \%$ dengan rata-rata nilai adalah 3,85 (suka) dan penilaian terendah terdapat pada A5 dengan subtitusi $50 \%$ dan $50 \%$ dengan rata-rata nilai 1,85 (tidak suka).

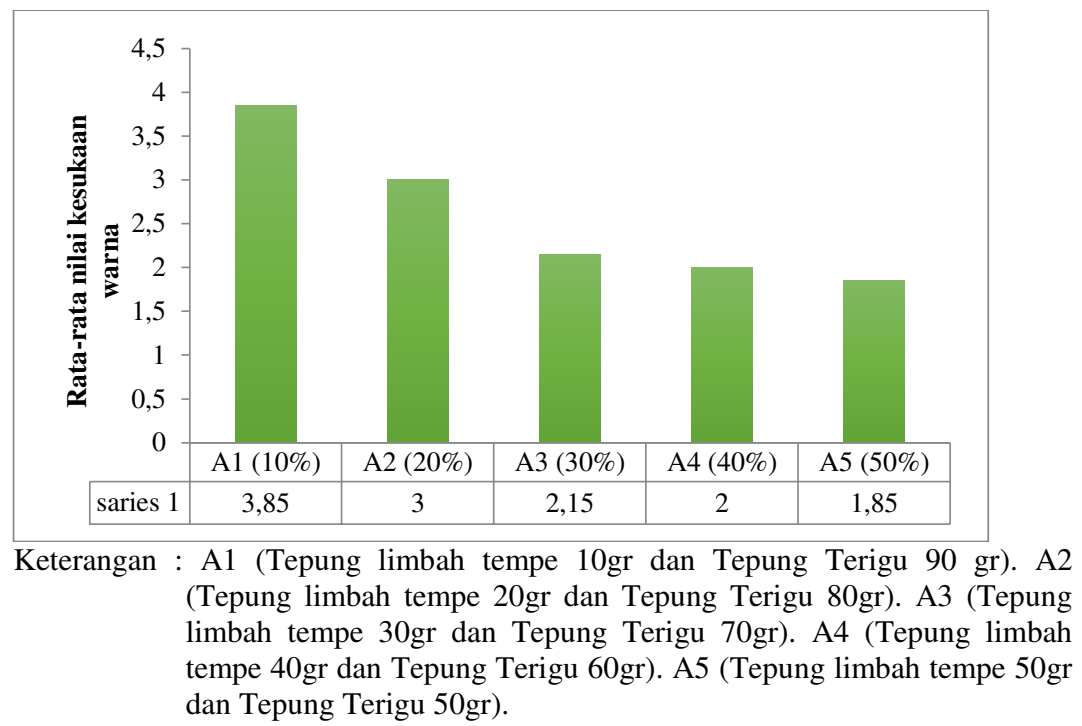

Gambar 7. Organoleptik warna mie kering tersubstitusi tepung limbah tempe 


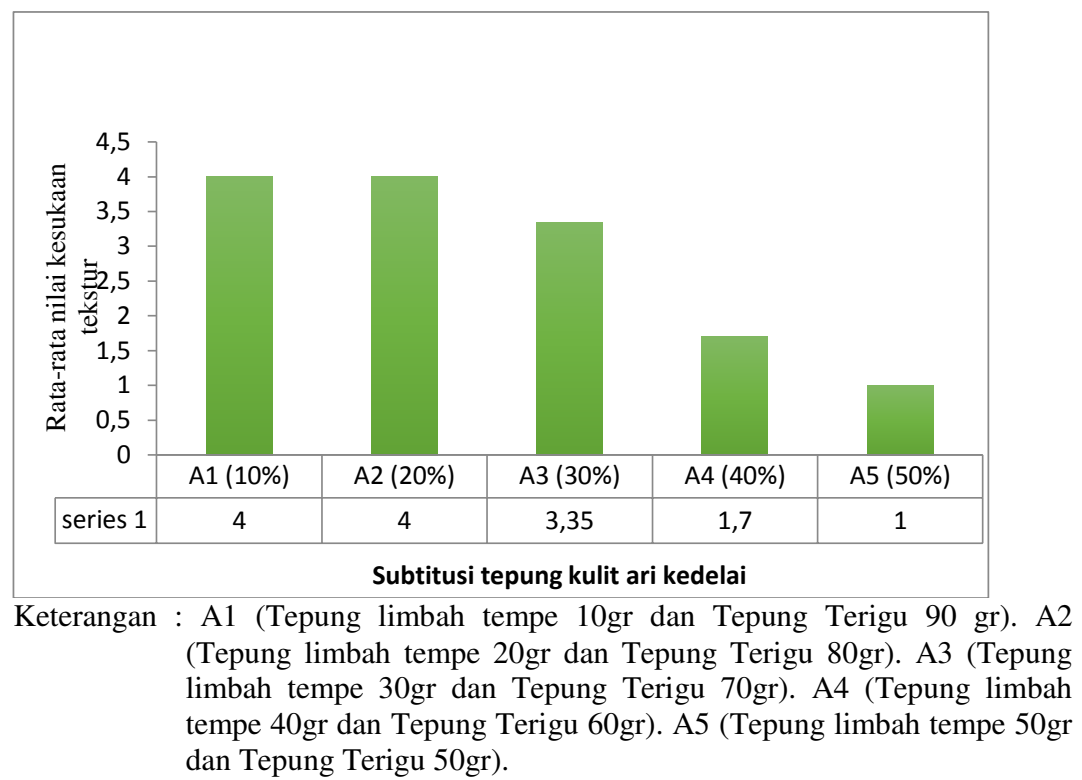

Gambar 8. Organoleptik tekstur mie kering tersubstitusi tepung limbah tempe

\section{Tekstur}

Dari uji organoleptik terhadap tekstur mie kering yang dihasilkan dapat dilihat pada gambar 8. Dari gambar diatas dapat diketahui bahwa rata-rata nilai yang dapat mempelihatkan kesukaan 20 orang panelis yaitu pada perlakuan 1 dan 2 yaitu A1 dan A2 dengan subtitusi $10 \%$ dengan rata-rata nilai adalah 4 (suka) dan penilaian terendah terdapat pada A5 dengan subtitusi 50\% dan $50 \%$ dengan rata-rata nilai 1 (tidak suka).

\section{Indeks Efektivitas}

Penentuan pelaksaan terbaik mie kering tersubstitusi limbah tempe dilakukan dengan menggunakan metode indeks efektivitas. Metode ini dilakukan pada parameter uji kimiawi yang meliputi uji kadar protein dan kadar air, uji fisik meliputi daya patah dan cooking time, serta uji organoleptik meliputi rasa, warna, aroma dan tekstur.

Hasil perhitungan menunjukkan perlakuan terbaik terdapat pada perlakuan A1 (tepung terigu 90gr tepung ampas tempe 10gr) dengan ketentuan fisiko kimia kadar protein $10,70 \%$, kadar air $9,65 \%$, daya patah 1,49 $(\mathrm{N})$, cooking time 2,42 (menit), serta organoleptik dengan ketentuan rasa 3 (netral), warna 3,85 (suka), aroma 4 (suka), dan tekstur 4 (suka).

Tabel 1. Perlakuan terbaik mie kering

\begin{tabular}{cc}
\hline Perlakuan & Rata-Rata \\
\hline A1 (tepung terigu 90gr tepung limbah tempe 10gr) & $0,815^{* 1}$ \\
A2 (tepung terigu 80gr tepung limbah tempe 20gr) & $0,724^{* 2}$ \\
A3 (tepung terigu 70gr tepung limbah tempe 30gr) & $0,481^{* 3}$ \\
A4 (tepung terigu 60gr tepung limbah tempe 40gr) & 0,374 \\
A5 (tepung terigu 50gr tepung limbah tempe 50gr) & 0,185 \\
\hline
\end{tabular}

Ket : ${ }^{* 1}$ : terbaik $1,{ }^{* 2}$ : terbaik $2,{ }^{* 3}$ : terbaik 3 


\section{KESIMPULAN DAN SARAN}

\section{Kesimpulan}

Berdasarkan penelitian pengaruh substitusi tepung limbah tempe terhadap kualitas mie kering dapat disimpulkan sebagai berikut.

1. Substitusi tepung limbah tempe terbaik fisiko kimia terdapat pada perlakuan A1 (tepung terigu 90gr tepung ampas tempe 10gr) dengan kriteria kadar protein $10,70 \%$, kadar air $9,65 \%$, daya patah 1,49 $(\mathrm{N})$, dan cooking time 2,42 (menit).

2. Substitusi tepung limbah tempe terbaik organoleptik terdapat pada perlakuan A1 (tepung terigu 90gr tepung ampas tempe 10gr) dengan kriteria rasa 3(netral), warna 3,85 (suka), aroma 4 (suka), dan tekstur 4 (suka).

3. Kombinasi perlakuan terbaik fisiko kimia dan organoleptik terdapat pada perlakuan A1 (tepung terigu 90gr tepung ampas tempe $10 \mathrm{gr}$ ) dengan kriteria kadar protein $10,70 \%$, kadar air $9,65 \%$, daya patah 1,49 $(\mathrm{N})$, cooking time 2,42 (menit), rasa 3 (netral), warna 3,85 (suka), aroma 4 (suka), dan tekstur 4 (suka).

\section{Saran}

Perlu dilkakukan penelitian lebih lanjut, dalam pembuatan mie kering subtitusi tepung terigu dengan tepung daun mangga yang berhubungan dengan penyimpanan mie kering, untuk mengetahui seberapa jauh produk tersebut tahan selama penyimpanan dan masih memenuhi kriteria mutu tertentu.

\section{DAFTAR PUSTAKA}

Askar, S dan Sugiarto. (2005). Uji Kimiawi Dan Organoleptik Sebagai Uji Mutu Yoghurt. Prosiding Temu Teknis Nasional Tenaga Fungsional Peretanian. Bogor. Balai penelitian ternak. Ciawi bogor.

Astawan, M. (2008). Membuat Mi dan Bihun. Penebar Swadaya. Jakarta
Badan Standardisasi Nasional Indonesia. (1992). Mi Kering. SNI: 01-29741992.Dewan Standarisasi Nasional

Bogasari. (2011). Seputar Tepung Terigu. PT ISM Bogasari Flour Mills. Jakarta.

De Garmo, Sullevan WE., CR Canana. (1984). Engineerimg Economis. New York, Ed. Macmilland Publ. Co.

Halwan, C, A dan Nisa, F, C. (2015). Pembutan Mie Kering Gembili Dan Bekatul ( Kajian Proporsi Terigu : Gembili dan Penambahan Bekatul). Jurnal Pangan dan Agroindustri, 3 (4).

Khomsan, A dan A, Faisal. (2008). Sehat itu Mudah, Wujudkan Hidup Sehat Dengan Makanan Tepat. PT Mizan Publika. Jakarta

Pipit. (2009). Respon Produksi Sususapi Friesian Holstein Terhadap Pemberian Suplemen Biomineral Dienkapsulasi. Skripsi. Fakultas Peternakan. Institut Pertanian Bogor.

Winarno F.G. (2004). Kimia Pangan dan Gizi. PT Gramedia Pustaka Utama. Jakarta

Winarti, S., Susiloningsih E,K,B., Fasroh, F,Y,Z. (2017). Karakteristik Mi Kering Dengan Substitusi Tepung Gembili dan Penambahan Plastiziser Gms (GliserolMono Stearat). Agrointek, 11 (2).

Yurleni, Y. (2017). Substitusi Kulit Ari Kedelai Pada Pakan Konsentrat Terhadap Produktivitas Sapi Po Dan Kerbau. Jurnal Ilmu Peternakan, 20 (1): 69-76. 